\title{
Perilaku Ekonomi : Literasi Ekonomi, Kelompok Teman Sebaya, dan Kontrol Diri
}

\author{
Puspa Eka Widyawati \\ e-mail: puspawidya1997@gmail.com \\ Lilik Sri Hariani \\ e-mail: liliksrihariani@unikama.ac.id \\ Udik Yudiono \\ e-mail: u_yudiono@unikama.ac.id
}

(Program Studi Pendidikan Ekonomi, Fakultas Ekonomika dan Bisnis, Universitas Kanjuruhan, Malang)

\begin{abstract}
ABSTRAK : Tujuan dari penelitian ini adalah untuk mengetahui pengaruh literasi ekonomi, kelompok teman sebaya, dan kontrol diri terhadap perilaku ekonomi mahasiswa Prodi Pendidikan Ekonomi Universitas Kanjuruhan Malang. Penelitian ini menggunakan metode regresi linier berganda dan pendekatan kuantitatif. Populasi dalam penelitian ini adalah mahasiswa prodi pendidikan ekonomi tahun angkatan 2016-2019. pengambilan sampel dalam penelitian ini menggunakan teknik sampel jenuh dengan mengambil keseluruhan populasi berjumlah 87 mahasiswa. Berdasarkan analisis data diperoleh bahwa (1) literasi ekonomi, kelompok teman sebaya, dan kontrol diri berpengaruh secara simultan dan signifikan terhadap perilaku ekonomi mahasiswa; (2) literasi ekonomi berpengaruh signifikan terhadap perilaku ekonomi mahasiswa; (3) kelompok teman sebaya berpengaruh signifikan terhadap perilaku ekonomi; dan, (4) kontrol diri berpengaruh signifikan terhadap perilaku ekonomi mahasiswa Prodi Pendidikan Ekonomi Universitas Kanjuruhan Malang
\end{abstract}

Kata kunci - Literasi, teman sebaya, kontrol, perilaku ekonomi

ABSTRACT: The purpose of this study was to determine the effect of economic literac, peer groups, and selfcontrol on the economic behavior students from the Department of Economic Education University of Kanjuruhan Malang. This study uses multiple linear regression methods and quantitative approaches. The population in this study were students of economic education study program year 2016-2019. Sampling in this study used a saturated sample technique by taking a total population of 87 students. Based on the analysis of the data obtained that (1) economic literacy, peer groups, and self-control simultaneously and significantly influence the economic behavior of students; (2) economic literacy has a significant effect on the economic behavior of students; (3) peer groups have a significant effect on economic behavior; and, (4) self-control has a significant effect on the economic behavior of students of Economic Education Study Program in Kanjuruhan University Malang

Keywords - literacy, peer, control, economic behavior 


\section{PENDAHULUAN}

Semakin berkembangnya teknologi mempermudahkan masyarakat Indonesia terutama anak muda untuk mengakses informasi tentang gaya hidup jaman sekarang. Hal ini seringkali terjadi dikalangan mahasiswa yang masuk usia remaja akhir. Perkembangan jaman semakin modern akan berdampak pada tingkat konsumsi mahasiswa, hal tersebut dikarenakan semakin beragamnya kebutuhan yang harus dipenuhinya. Tingkat konsumsi mahasiswa dapat dilihat dari seberapa banyak mereka menggunakan pendapatan (uang saku) mereka untuk memenuhi kebutuhannya dalam berbelanja. Seiring dengan meningkatnya gaya hidup juga menuntut mahasiswa untuk selalu berpenampilan menarik. Penampilan menarik ini tidak lepas dari make up, perawatan kecantikan, pakaian yang modis dan barang-barang model keluaran baru yang sedang tren.

Mahasiswa yang masih dapat dikatakan sebagai remaja ini sebagian besar cenderung memiliki perilaku konsumtif, Hal ini berkaitan dengan karakter remaja yang masih labil dan seringkali terpengaruh dengan lingkungannya. Perilaku konsumsi mahasiswa yang masuk dalam kelompok konsumen remaja ini dapat dipengaruhi oleh beberapa faktor, Setiadi (2013:10) menyebutkan ada beberapa faktor yang dapat berpengaruh terhadap perilaku konsumen diantaranya adalah faktor kebudayaan, faktor sosial, faktor pribadi, dan faktor psikologis. salah satunya adalah proses belajar, pengetahuan mempunyai peran penting dalam membentuk perilaku seseorang termasuk dalam kegiatan ekonomi.

Pengetahuan dasar ekonomi atau literasi ekonomi sangat penting dalam kehidupan mahasiwa, Menurut Haryono (2012) Mengungkapkan bahwa seseorang yang dalam kehidupannya memiliki literasi ekonomi yang kurang baik biasanya tindakan ekonominya tidak rasional. Daroin (2010) menyatakan bahwa literasi ekonomi adalah salah satu keadaan yang bisa menggambarkan seseorang dapat memahami masalah perkonomian dengan baik, yang berhubungan dengan kehidupan sehari-hari dalam memenuhi setiap kebutuhan hidupnya.. Sebagai mahasiswa yang berada pada masa remaja akhir-dewasa awal perilaku konsumsi tidak terlepas dari pengaruh lingkungan teman-teman sebayanya. Menurut Mappiare dalam Murisal (2012:202) mengatakan bahwa remaja tidak jarang dihadapkan dengan penerimaan dan penolakan teman sebaya dalam lingkup pergaulannya, agar dengan baik diterima didalam kelompoknya maka biasanya mereka sering mengikuti hal-hal yang sama dengan kelompok sebayanya. Hal tersebut dapat terjadi karena remaja saat ini mudah terpengaruh dengan lingkungan sekitarnya dan tidak diimbangi dengan kontrol diri, yang akhirnya berdampak pada tingkat konsumsinya. Menurut Gufron dan Rini (2010) kontrol diri merupakan kemampuan yang dimiliki seseorang untuk membantuk membentuk perilakunya agar membawa ke arah konsekuensi positif. Kontrol diri dapat dijadikan pengendali tingkah laku sebelum mengambil tindakan, Sehingga semakin tinggi kontrol diri yang dimiliki akan semakin baik pengendalian terhadap tindakan berkonsumsi.

Penelitian oleh rizky fiqriyah, dkk. (2016), hasil penelitian ini menjukkan bahwa pemahaman dasar ekonomi mempunyai pengaruh positif terhadap rasionalitas perilaku konsumsi siswa. Akan tetapi nilai koefisien determinasinya masih tergolong rendah yaitu $23 \%$, yang berarti ada beberapa faktor lain yang dapat mempengaruhi perilaku konsumsi yang belum diteliti. Penelitian oleh Anggena Pricila, dkk (2013), menunjukkan hasil adanya pengaruh yang positif pergaulan teman sebaya terhadap rasionalitas konsumsi mahasiswa. sedangkan penelitian lain oleh Lina Fauzul Muna (2018), hasil penelitian ini menunjukkan bahwa pergaulan teman sebaya secara parsial tidak berpengaruh signifikan terhadap rasionalitas konsumsi mahasiswa.

Berdasarkan latar belakang diatas maka peneliti berkeinginan untuk melakukan penelitian dengan judul "Pengaruh Literasi Ekonomi, Kelompok Teman Sebaya, dan Kontrol Diri terhadap Perilaku Ekonomi Mahasiswa Prodi Pendidikan Ekonomi Universitas Kanjuruhan Malang. Diadakannya penelitian ini adalah dengan tujuan untuk: 1) mengetahui pengaruh literasi ekonomi, kelompok teman sebaya, dan kontrol diri terhadap perilaku ekonomi mahasiswa. 2) mengetahui 
pengaruh literasi ekonomi terhadap perilaku ekonomi mahasiswa. 3) mengetahui pengaruh kelompok teman sebaya terhadap perilaku ekonomi mahasiswa. dan, 4) mengetahui pengaruh kontrol diri terhadap perilaku ekonomi mahasiswa Prodi Pendidikan Ekonomi Universitas Kanjuruhan Malang.

\section{TINJAUAN PUSTAKA}

Perilaku ekonomi merupakan cabang ilmu yang mempelajari ilmu ekonomi tentang perilaku agen dalam situasi perekonomian. Salah satu tujuan utama perilaku ekonomi yaitu untuk menggambarkan dan menjelaskan mengapa dalam beberapa situasi, agen tersebut berperilaku tidak rasional atau irasional (Jarboui dan Boujelbene, 2012:202). Perilaku seseorang dalam kegiatan ekonomi juga dapat menggambarkan bagaimana seseorang tersebut mendapatkan dan menggunakan setiap barang dan jasa yang mereka butuhkan dengan pengambilan keputusan yang baik dan rasional. Menurut Rokhmani (2013), menyatakan bahwa dalam pandangan ilmu mikro ekonomi kegiatan ekonomi seorang mahasiswa hanya melakukan tindakan konsumsi, sehingga perilaku ekonomi mahasiswa masuk dalam kategori perilaku rumah tangga yaitu rumah tangga ekonomi yang menggambarkan aktivitas konsumsi yanmg dilakukannya sebagai kegiatan utama sehari-hari. Menurut Yunikawati (2012) untuk mengukur perilaku ekonomi seseorang dapat menggunakan sub variabel harga (kesesuaian harga barang dengan kualitas, kesesuaian harga barang dengan manfaat, kesesuaian harga barang dengan model, dan kecenderungan untuk bisa berhemat) dan skala prioritas (kebutuhan paling mendesak yang harus segera dipenuhi, barang yang memiliki nilai guna maksimal, kemampuan keuangan yang miliki.

Pemahaman akan dasar ilmu ekonomi atau yang biasa disebut dengan melek ekonomi adalah kemampuan yang dimiliki oleh seseorang agar dapat menerapkan konsep-konsep ekonomi dalam kehidupan sehari-harinya untuk mengambil setiap keputusan tentang penghasilan yang dimilikinya dan bagaimana mengatur masalah keuangannya ( Pandey \& Bhattacharya, 2012:3). Pendapat lain yang dikemukakan oleh Peter Sina (2012: 135) menyatakan bahwa literasi ekonomi merupakan alat yang dapat berfungsi untuk mengubah tindakan ekonomi seseorang dalam hal mengatur pengeluarannya dan dalam mengambil keputusan agar lebih cerdas dan bijak. Misalnya, bagaimana memanfaatkan penghasilan yang dimiliki untuk memenuhi kebutuhannya dan menyisihkan sebagian uangnya untuk ditabung. NCEE sebagai lembaga sosialisasi melek ekonomi di Amerika mengembangkan 20 indikator untuk mengukur pemahaman dasar ekonomi seseorang.

Menurut Yudha dan Idris (2014:4) menyatakan bahwa teman sebaya merupakan keadaan dimana dua atau lebih orang-orang dengan rentan usia dan status yang sama yang beriteraksi satu sama lain dan dapat memberikan dampak negatif maupun positif. Nilai-nilai pribadi seseorang dalam lingkungan keluarga, sekolah maupun masyarakat sekitarnya dapat dipengaruhi pergaulan teman sebaya, misalnya dalam bentuk sikap maupun perilaku. Kelompok teman sebaya dapat diukur menggunakan indikator diantaranya interaksi sosial teman sebaya, keterlibatan individu dalam beraksi, dukungan teman sebaya, dan keintiman atau kasih sayang teman sebaya. Kontrol diri merupakan suatu kemampuan seseorang mengenali situasi dalam dirinya dan lingkungan sekitarnya (Ghufron, 2014: 21). Selain itu, juga merupakan kemampuan mengelola berbagai faktor perilaku sesuai dengan situasi dan kondisi seseorang, kontrol diri dapat digunakan untuk mengendalikan dan mengubah perilaku seseorang agar dapat sesuai dengan orang lain disekitarnya guna untuk dapat diterima dengan baik dlingkungannya. Kontrol diri dapat diukur melalui aspek -aspek kontrol diri yang dijakdikan indikator diantaranya adalah kontrol perilaku (behavior control), kontrol kognitif (cognitiv control), dan mengontrol kepuasan (decesional control).

Penelitian relevan yang hampir sama yaitu penelitian oleh Ning Faidah, dkk (2018), hasil dari penelitian menunjukkan bahwa variabel kontrol diri mempunyai pengaruh positif terhadap 
perilaku ekonomi siswa. Penelitian yang dilakukan oleh Valdyan Drifanda (2018), penelitian menunjukkan hasil pada variabel teman sebaya dan literasi ekonomi masing-masing terdapat pengaruh positif dan signifikan terhadap perilaku ekonomi mahasiswa, yang artinya bahwa kegiatan ekonomi seseorang dapat dipengaruhi oleh lingkungan disekitarnya.

\section{METODE}

Penelitian ini menggunakan pendekatan kuantitatif. Pengambilan data dalam Penelitian ini dilaksanakan di Universitas Kanjuruhan Malang pada mahasiswa Prodi Pendidikan Ekonomi Universitas Kanjuruhan Malang tahun akademik 2019/2020, dengan menggunakan angket atau kuesioner. Populasi penelitian ini adalah mahasiswa program studi pendidikan ekonomi angkatan 2016-2019 dengan jumlah 87 mahasiswa. Teknik yang digunakan untuk pengambilan sampel dalam penelitian ini menggunakan teknik sampel jenuh karena jumlahnya kurang dari 100. Teknik sampel jenuh merupakan teknik-teknik penentuan jumlah sampel bila semua bagian dalam populasi digunakan sebagai sampel (Sugiyono, 2014). Jumlah sampel dalam penelitian ini adalah 87 mahasiswa, yaitu dengan mengambil keseluruhan populasi sebagai sampel.

Sebelum penelitian dilakukan uji coba instrumen kepada 30 responden dengan menggunakan angket. Analisis yang digunakan untuk uji instrumen yaitu dengan menggunakan uji validitas dan realibilitas. Analisis penelitian ini menggunakan analisis regresi linear berganda dengan menggunakan perhitungan statistik dan dilakukan pengujian hipotesis yang terdiri dari : Uji F, Uji t, Dan Uji $\mathbf{R}^{2}$. Sebelum menggunakan analisis regresi berganda dilakukan uji prasyarat dulu yaitu uji asumsi klasik yang terdiri dari uji normalitas, uji heteroskedastisitas, uji multikolinieritas, dan uji autokorelasi. Dalam pengelolahan data peneliti menganalisis dengan menggunakan bantuan program SPSS 22.00 for windows.

\section{PEMBAHASAN}

Penelitian ini terdiri dari tiga variabel bebas yaitu literasi ekonomi, kelompok teman sebaya, kontrol diri dan satu variabel terikat yaitu perilaku ekonomi. Teknik analisis data dalam penelitian ini menggunakan analisis regresi linear berganda digunakan untuk mengetahui besarnya pengaruh antar variabel-variabel bebas dan variabel terikat. Hasil analisis regresi linear berganda dapat dilihat pada Tabel 1

Tabel 1. Hasil Analisis Regresi berganda

\begin{tabular}{|c|c|c|c|c|c|c|}
\hline \multicolumn{7}{|c|}{ Coefficient $^{a}$} \\
\hline & \multirow[b]{2}{*}{ Model } & \multicolumn{2}{|c|}{$\begin{array}{l}\text { Unstandardized } \\
\text { Coefficients }\end{array}$} & \multirow{2}{*}{$\begin{array}{c}\begin{array}{c}\text { Standardized } \\
\text { Coefficients }\end{array} \\
\text { Beta }\end{array}$} & \multirow[b]{2}{*}{$\mathrm{t}$} & \multirow[b]{2}{*}{ Sig } \\
\hline & & B & $\begin{array}{l}\text { Std. } \\
\text { Error }\end{array}$ & & & \\
\hline \multirow[t]{4}{*}{1} & (Constant) & 13,317 & 6,634 & & 2,008 & 048 \\
\hline & Literasi Ekonomi (X1) & ,573 & ,227 & 238 & 2,528 & ,013 \\
\hline & Kelompok Teman sebaya (X2) & ,434 & , 169 & 254 & 2,568 & ,012 \\
\hline & Kontrol Diri (X3) & ,565 & 166 & ,334 & 3,393 & ,001 \\
\hline
\end{tabular}

Berdasarkan Tabel 1 persamaaan regresi yang dapat disusun adalah : $\mathrm{Y}=13,317+$ $0,573(\mathrm{X} 1)+0,434(\mathrm{X} 2)+0,565(\mathrm{X} 3)$. Besarnya pengaruh literasi ekonomi dapat dilihat dari nilai koefisien 
regresi sebesar 0,573, dikarenakan nilainya positif maka pengaruhnya searah. Nilai koefisien regresi kelompok teman sebaya sebesar 0,434 menunjukkan besarnya pengaruh kelompok teman sebaya terhadap perilaku ekonomi dikarenakan nilainya positif maka pengaruhnya searah. Besarnya pengaruh kontrol diri dapat dilihat dari koefisiean regresi sebesar 0,565.dikarenakan nilainya positif maka pengaruhnya searah. Berdasarkan pemaparan hasil analisis diatas, dapat diketahui variabel bebas berpengaruh dengan variabel terikat. Variabel literasi ekonomi memiliki pengaruh terbesar terhadap perilaku ekonomi, Karena nilai $\mathrm{X}_{1}$ nilai koefisien determinannya lebih besar daripada $\mathrm{X}_{2}$ (kelompok teman sebaya) dan $X_{3}$ (kontrol diri) yaitu $(0,573>0,434)$ dan $(0,573>0,565)$.

Berdasarkan Uji F yang digunakan untuk menganalisis pengaruh secara simultan sehingga dapat diambil hipotesis pertama $\left(\mathrm{H}_{1}\right)$ yaitu variabel bebas literasi ekonomi $\left(\mathrm{X}_{1}\right)$, kelompok teman sebaya $\left(\mathrm{X}_{2}\right)$ dan kontrol diri $\left(\mathrm{X}_{3}\right)$ terhadap perilaku ekonomi. Hasil uji dari bantuan software SPSS 22.00 for windows yang menunjukkan hasil uji $\mathrm{F}$ dari perhitungan statistik. Hasil uji $\mathrm{F}$ dapat dilihat pada Tabel 2. Dari perhitungan statistik diperoleh hasil uji F statistik dari tabel Anova untuk menguji hipotesis yang diajukan adalah diperoleh nilai $\mathrm{F}$ sebesar 11,329 dengan tingkat signifikansi 0,000 karena tingkat signifikansi lebih kecil dari 0,05, maka $\mathrm{H}_{01}$ ditolak dan $\mathrm{H}_{\mathrm{a} 1}$ diterima. Nilai koefisien determinasi pada penelitian ini menunjukkan bahwa literasi ekonomi, kelompok teman sebaya, dan kontrol diri secara bersama-sama mempengaruhi perilaku ekonomi mahasiswa.

Tabel 2. Hasil Uji F

\begin{tabular}{|l|l|r|r|r|r|r|}
\hline \multicolumn{7}{|c|}{ ANOVA $^{\text {a }}$} \\
\hline \multicolumn{1}{|l|}{ Model } & Sum of Squares & \multicolumn{1}{c|}{ Df } & Mean Square & F & Sig. \\
\hline 1 & Regression & 1649,334 & 3 & 549,778 & 11,329 & $\begin{array}{r}, 00 \\
0^{\mathrm{b}}\end{array}$ \\
\cline { 2 - 7 } & Residual & 4027,931 & 83 & 48,529 & & \\
\cline { 2 - 7 } & Total & 5677,264 & 86 & & & \\
\hline
\end{tabular}

Perilaku ekonomi adalah tindakan ekonomi yang dilakukan setiap manusia guna memenuhi kebutuhan hidupnya untuk mencapai kesejahteraan. Dari hasil penelitian ini perilaku ekonomi mahasiswa dipengaruhi oleh literasi ekonomi yang miliki mahasiswa. Sebagai mahasiswa Pendidikan ekonomi tentunya ilmu ekonomi sudah tidak asing lagi, terlebih pada dasarnya kegiatan ekonomi merupakan salah satu kegiatan pokok yang dilakukan setiap manusia dalam kehidupan sehari-hari. Hal tersebut didukung dari hasil penelitian ini bahwa mahasiswa memiliki pemahaman dasar ekonomi yang baik sehingga perilaku ekonominya rasional. Selain pemahaman dasar ekonomi, perilaku ekonomi mahasiswa juga didukung dengan kelompok teman sebaya yang baik, dengan lingkungan sosial yang baik maka akan membawa pengaruh positif dalam kehidupan mahasiswa. Mahasiswa pendidikan ekonomi juga mempunyai kontrol yang baik dalam dirinya, dengan mempunyai pengendalian diri yang baik tersebut mereka mampu menahan setiap pengaruh dalam diri maupun dari luar yang akan berakibat merugikan bagi dirinya. Dan dapat berfikir lebih rasional dalam membelanjakan uangnya dan mengontrol setiap pengeluarannya agar terhindar dari perilaku konsumtif.

Berdasarkan Nilai $\mathbf{R}^{2}$ mampu menerangkan variabel dengan regresi linear berganda. yangdigunakan untuk mengukur besarnya proporsi dari variabel bebas. Nilai $\mathbf{R}^{2}$ berkisar $0-1$, apabila nilai koefisien determinasi mendekati angka 1 maka dapat dikatakan bahwa model regresi semakin baik dalam menjelaskan pengaruh variabel bebas terhadap variabel terikat. Hasil uji $\mathbf{R}^{2}$ dapat dilihat pada Tabel 3. Berdasarkan Tabel 3 dengan menggunakan perhitungan statistik 
diperoleh nilai R square sebesar 0,291 yang maknanya literasi ekonomi, kelompok teman sebaya, dan kontrol diri mampu memberikan kontribusi sebesar 29,1\% terhadap perilaku ekonomi. Koefisien determinasi sebesar 29,1\% mempunyai makna bahwa ketiga variabel independen yaitu literasi ekonomi, kelompok teman sebaya, dan kontrol diri memberikan kontribusi terhadap perilaku ekonomi mahasiswa pendidikan ekonomi, hal tersebut karena adanya literasi ekonomi yang baik yang dimiliki oleh mahasiswa, sehingga selain mahasiswa paham dalam teori mereka juga mampu menerapkan ilmu ekonomi yang dimilikinya dalam kehidupan sehari-hari sehingga membuat perilaku ekonomi mereka baik dan rasional.

Selain literasi tindakan ekonomi mahasiswa juga didukung dengan lingkungan sosial teman sebaya yang baik yang mendukung perilaku ekonomi mahasiswa sehingga mahasiswa terhindar dari pengaruh budaya konsumtif. Dan dengan tingkat kontrol diri atau pengendalian yang baik mahasiswa akan mampu mengendalikan setiap keinginan yang ada dalam dirinya dan tidak mudah terpengaruh pada gaya hidup yang tingi dan cenderung boros, sehingga mahasiswa akan memiliki perilaku ekonomi yang rasional. Berdasarkan besarnya nilai koefisien determinasi di atas yaitu sebesar 0,291 maka kesimpulannya adalah kontribusi variabel independen pada perilaku ekonomi masih tergolong cukup rendah. Dari nilai tersebut dapat disimpulkan bahwa perilaku ekonomi mahasiswa tidak hanya dipengaruhi oleh literasi ekonomi, kelompok teman sebaya dan kontrol diri. Artinya sisanya sebesar $70,9 \%$ dapat dikatakan bahwa ada faktor-faktor lain yang dapat mempengaruhi perilaku ekonomi diluar variabel yang diteliti.

Tabel 3. Hasil Uji $\mathbf{R}^{2}$

\begin{tabular}{|l|c|c|c|cr|}
\hline \multicolumn{7}{|c|}{ Model Summary $^{\mathrm{b}}$} \\
\hline \multicolumn{1}{|c|}{ Model } & $\mathrm{R}$ & $\mathrm{R}$ & $\begin{array}{c}\text { Adjusted R } \\
\text { Square }\end{array}$ & \multicolumn{2}{|c|}{$\begin{array}{c}\text { Std. Error of the } \\
\text { Estimate }\end{array}$} \\
\hline 1 &, $539 \mathrm{a}$ &, 291 &, 265 & & 6,966 \\
\hline
\end{tabular}

Berdasarkan analis data yang dilakukan melalui Uji t yang digunakan untuk menguji pengaruh secara parsial atau sendiri-sendiri dari masing-masing variabel bebas dengan variabel terikat. Hasil perhitungan statistik pada penelitian ini dapat dilihat pada Tabel 4

Tabel 4. Hasil Uji $t$

\begin{tabular}{|c|l|c|c|l|}
\hline \multicolumn{5}{|c|}{ Coefficients $^{\mathrm{a}}$} \\
\hline \multicolumn{2}{|c|}{ Model } & $\mathrm{t}$ & Sig. & Keterangan \\
\hline 1 & (Constant) & 2,008 &, 048 & \\
\hline \multirow{3}{*}{} & Literasi Ekonomi $\left(\mathrm{X}_{1}\right)$ & 2,528 &, 013 & Signifikan \\
\cline { 2 - 5 } & Kelompok Teman sebaya $\left(\mathrm{X}_{2}\right)$ & 2,568 &, 012 & signifikan \\
\cline { 2 - 5 } & Kontrol Diri $\left(\mathrm{X}_{3}\right)$ & 3,393 &, 001 & signifikan \\
\hline
\end{tabular}

Berdasarkan Tabel 4 hasil yang diperoleh untuk menguji hipotesis kedua $\left(\mathrm{H}_{2}\right)$ adalah diperoleh nilai thitung sebesar 2,528 dengan nilai signifikasi 0,013 atau nilai signifikansi $<0,05$ yang artinya, literasi ekonomi memiliki pengaruh yang positif dan signifikan secara parsial terhadap perilaku ekonomi mahasiswa prodi Pendidikan Ekonomi Universitas Kanjuruhan Malang. Dari analisis data yang diperoleh dapat dikatakan bahwa Mahasiswa pendidikan ekonomi memiliki pemahaman dasar ekonomi atau literasi ekonomi yang baik, dengan pemahaman yang baik tentang ilmu ekonomi yang dimiliki mereka mampu menerapkan ilmu ekonomi yang mereka miliki dalam 
kehidupan sehari-hari sehingga kegiatan konsumsi yang dilakukan menjadi rasional. Artinya, dari beberapa faktor yang dapat mempengaruhi perilaku ekonomi mahasiswa salah satu faktornya adalah Literasi ekonomi atau pemahaman dasar ekonomi. Dapat dikatakan, bahwa Seorang mahasiswa yang memiliki pemahaman dasar ekonomi yang baik akan lebih cerdas dalam mengambil keputusan berkonsumsi yang rasional. Literasi ekonomi dapat membantu memecahkan berbagai permasalahan ekonomi, misalnya bagaimana seseorang mengambil pilihan alternatif guna untuk memenuhi kebutuhan hidupnya dan belajar mengelola penghasilan yang dimiliki dengan mengatur setiap pengeluaran agar dapat menyeimbangkan setiap biaya yang sudah dikeluarkan dengan hasil (manfaat) yang diperoleh guna mencapai kesejahteraan. Dapat disimpulkan bahwa dengan adanya pemahaman ekonomi yang baik dan penerapan yang baik, akan membuat seorang mahasiswa dalam memenuhi kebutuhannya lebih rasional ketika mengambil keputusan berkonsumsi.Hasil penelitian ini sejalan dengan penelitian yang dilakukan oleh Rizky Fiqriyah (2016).

Berdasarkan Tabel 4 untuk menguji hipotesis ketiga $\left(\mathrm{H}_{3}\right)$ adalah diperoleh nilai thitung sebesar 2,568 dengan nilai signifikasi 0,012 atau nilai signifikansi $<0,05$ yang artinya kelompok teman sebaya memiliki pengaruh yang signifikan dan positif secara parsial terhadap perilaku ekonomi mahasiswa prodi Pendidikan Ekonomi Universitas Kanjuruhan Malang. Mahasiswa pendidikan ekonomi memiliki lingkungan sosial yang baik dengan teman sebayanya.. Dengan lingkungan yang baik akan berdampak positif bagi kehidupan mahasiswa, dengan dukungan dan motivasi dari teman sebayanya akan membantu tindakan konsumsinya lebih mengarah pada pola konsumsi yang rasional dan bermanfaat bagi kehidupan sehari-harinya. Kelompok teman sebaya juga dapat mempengaruhi pola pikir seseorang dalam melakukan tindakan ekonomi, termasuk tindakan ekonomi seorang mahasiswa. Tindakan ekonomi yang dimaksud adalah dalam hal berkonsumsi, pengambilan keputusan seorang konsumen dalam membeli barang ataupun jasa seringkali dipengaruhi oleh pendapat dan pilihan teman-temannya. Hal tersebut dikarenakan selera dan kebutuhan mereka hampir sama. Artinya ketika dalam hubungan kelompok teman sebaya saling memberikan saran dan pendapat yang positif terutama dalam hal berkonsumsi maka tindakan ekonomi yang dilakukan akan mengarah pada perilaku ekonomi yang baik. Kelompok teman sebaya yang baik akan memberikan pengaruh yang positif dalam kehidupan mahasiswa. misalnya saling mengingatkan untuk tidak boros dan menyisihkan uang untuk menabung. Hasil ini sejalan dengan penelitian yang dilakukan oleh Anggena Pricila, dkk (2013).

Berdasarkan Tabel 4 untuk menguji hipotesis kedua $\mathrm{H}_{4}$ adalah variabel kontrol diri $\left(\mathrm{X}_{3}\right)$ terdapat pengaruh yang signifikan dan positif secara parsial terhadap perilaku ekonomi mahasiswa Prodi Pendidikan Ekonomi Universitas Kanjuruhan Malang. Hal tersebut berdasarkan dari hasil uji t diperoleh nilai thitung sebesar 3,393 dengan nilai signifikansi 0,001 atau nilai signifikansi < 0,05. Mahasiswa pendidikan ekonomi memiliki kontrol diri yang baik, mereka cenderung tidak tergesagesa dalam membeli barang yang mereka inginkan. Dengan kontrol diri yang baik dalam dirinya membantu mereka untuk selalu mempertimbangkan setiap biaya yang dikeluarkan dengan hasil yang akan didapatnya nanti, sehingga mereka hanya akan membeli barang yang benar-benar mereka butuhkan. Kontrol diri erat kaitanya dengan keadaan yang menggambarkan seseorang mampu mengendalikan setiap dorongan-dorongan dan sifat emosional yang ada dalam dirinya. Sebagai bagian yang penting dalam mengatur perilaku ekonomi seseorang kontrol diri memiliki pengaruh yang cukup besar, karena berkaitan dengan bagaimana seseorang mengendalikan dirinya. Seorang mahasiswa yang mempunyai kontrol diri yang baik akan mampu mengontrol setiap pengeluarannya dan melawan keinginan-keinginan yang bukan mejadi kebutuhannya. Sebelum bertindak, seseorang akan memikirkan dahulu keputusan yang diambil dengan resiko yang akan diterima dikarenakan mereka mampu mengontrol dirinya dengan baik. penelitian yang dilakukan oleh Ning Faidah, dkk (2018) juga sesuai dengan hasil penelitian ini, yaitu kontrol diri berpengaruh terhadap perilaku ekonomi. 


\section{KESIMPULAN}

Berdasarkan hasil analisis dalam penelitian ini yang dapat diambil kesimpulan bahwa literasi ekonomi, kelompok teman sebaya, dan kontrol diri memiliki pengaruh yang signifikan secara simultan atau bersama-sama terhadap perilaku ekonomi mahasiswa Prodi Pendidikan Ekonomi Universitas Kanjuruhan Malang. Pada literasi ekonomi terdapat pengaruh yang signifikan secara parsial terhadap perilaku ekonomi. Kelompok teman sebaya berpengaruh signifikan secara parsial terhadap perilaku ekonomi. Kontrol diri juga mempunyai pengaruh yang signifikan secara parsial terhadap perilaku ekonomi mahasiswa Prodi Pendidikan Ekonomi Universitas Kanjuruhan Malang. Berdasarkan kesimpulan diatas, maka saran yang diajukan oleh peneliti kepada mahasiswa yakni untuk selalu bertindak rasional dalam berkonsumsi, tujuannya agar mahasiswa dapat menempatkan setiap kebutuhan yang harus dipenuhinya dan mengesampingkan keinginannya agar terhindar dari perilaku konsumtif. Dan untuk penelitian selanjutnya guna untuk mengetahui lebih lanjut faktorfaktor yang dapat mempengaruhi perilaku ekonomi, sebaiknya menggunakan variabel yang tidak diteliti dalam penelitian ini.

\section{DAFTAR PUSTAKa}

Anggena Pricilia. 2013. Pengaruh Pergaulan Teman Sebaya Terhadap Rasionalitas Ekonomi Mahasiswa Pendidikan Ekonomi FKIP Untan. Skripsi. Untan : Pontianak

Daroin, Ana Dhaoud. 2010. Pengaruh Kualitas Pembelajaran Ekonomi, Pengetahuan dasar Ekonomi (Economic Literacy dan Status Sosial Ekonomi Orang Tua terhadap Efisiensi dalam Berkonsumsi Siswa Kelas XI dan XII Ilmu Sosial SMAN 1 Malang. Tesis. Malang:UM.

Faidah, Ning. 2018. Pengaruh Pengalaman Ekonomi, Kontrol Diri Serta Pendapatan Siswa Terhadap Perilaku Ekonomi Siswa Sma Di Kecamatan Pasir Belengkong Kabupaten Paser. Jurnal Ekonomi Pendidikan dan Kewirausahaan Vol. 6 No. 1 Hal 59-82(online). https://journal.unesa.ac.id/index.php/jepk. Diakses pada 24 Desember 2020

Fiqriyah, Rizky, Wahyono, hari, Inayati, Ro'ufah. 2016. Pengaruh pengelolaan uang saku, modernitas, kecerdasan emosional, dan pemaham dasar ekonomi terhadap Rasionalitas perilaku konsumsi siswa kelas X IIS MAN 1 Malang. Jurnal Pendidikan Ekonomi, Vol.09, No.1(online). ttps://dx.doi.org/10.17977/UM014v09i12016p001. Di akses 30 Januari 2020

Gufron, M.N. dan S, Rini.R. 2014. Teori-Teori Psikologi. Jogjakarta: Ar-Ruzz Media

Haryono, Agung. 2012. Pengembangan Model-Model Pembelajaran Berbasis Economic Literacy siswa SMA. Jurnal Penelitian Pendidikan. 1. (Online):

1-11, (http://jpk.lemlit.um.ac.id), diakses pada 02 November 2019

Jarboui, Salmi., Younes Boujelbene. 2012. The Behavioral Approach an the Rationality Of Economic Decisions: Application to Bank Managers. Global Business and Management Reaserch: An International Journal, (Online), 205-219 (http://www.gbmr.ioksp.com), diakses 25 November 2019

Mappiare, Andi \& Murizal. 2012. Psikologi Remaja. Surabaya: Usaha Nasioanal

Pandey, Chancala \& Bhattacharya. (2012). Economic Literacy of Senior Secondary School Teachers: A Field Study. Journal of All India Association for Educational Research. Volume 24 No. 1. Diakses pada 20 Januari 2020

Peter G Sina. 2012. Literasi Ekonomi. Diakses dari http://ekonomi.kompasiana.com/moneter/2012/05/01/literasi ekonomi459579.html. Di akses pada 1 Desember 2019. 
Rokhmani, Lisa. 2013. Faktor-Faktor yang Berpengaruh Terhadap Perilaku Ekonomi Siswa SMA Kota Mojokerto. Disertasi tidak diterbitkan. Malang: PPs Um.

Setiadi, Nugroho J. 2013. Perilaku Konsumen. Jakarta: Kencana

Sugiyono. (2012). Metode Penelitian Kuantitatif dan Kualitatif dan R\&D. Bandung: Alfabeta

Yudha R. I. \& Idris. 2014. Pengaruh Lingkungan Sekolah, Teman Sebaya dan Motivasi Belajar Terhadap Hasil Belajar Siswa pada SMK Bidang Manajemen Bisnis Jurusan Pemasaran di Kecamatan Jambi Selatan Kota Jambi. Jurnal pendidikan (online). http/ejornal.unp.ac.id/index.php/mpe/article/download/424343/3333. Diakses tanggal 26 november 2019.

Yunikawati, N.A. 2012. Pengaruh Status Sosial Ekonomi Orang Tua, Pendidikan Ekonomi Keluarga terhadap Financial literacy dan Gaya Hidup serta dampaknya Pada Rasionalitas Konsumsi. Tesis tidak diterbitkan. Malang: PPs Um. 